\title{
PERBANDINGAN AKURASI ENSEMBLE ARIMA DALAM PERAMALAN CURAH HUJAN DI KOTA BATU, MALANG, JAWA TIMUR
}

\author{
Ria Faulina \\ e-mail: riafaulina1989@gmail.com
}

\begin{abstract}
In Indonesia, the climate change is important for food production. One effort to address the issue of climate change in agriculture is using a tactical approach to the development of methods for modeling and forecasting. This paper used ARIMA and ensemble ARIMA to forecast ten-daily rainfall prediction in six rainfall stations, Batu, Malang, East Java. The best model is measured by the smallest root of mean square errors (RMSE) in testing the datasets. ARIMA model for six rainfall stations showed better accuracy for 54 periods ahead than ensemble ARIMA.
\end{abstract}

Keywords: ARIMA, ensemble, Ten daily rainfall.

\begin{abstract}
ABSTRAK
Di Indonesia, perubahan pola iklim sangat mempengaruhi produksi pertanian. Salah satu upaya untuk mengatasi dampak perubahan iklim dalam pertanian saat ini adalah melalui pendekatan taktis dengan pengembangan metode dalam pemodelan dan peramalan. Dalam studi ini digunakan metode ARIMA sebagai model individu dan ensemble ARIMA sebagai model kombinasi untuk meramalkan rata-rata curah hujan dasaharian di enam stasiun Kota Batu, Malang, Jawa Timur. Keakuratan model dalam prediksi diukur berdasarkan kriteria RMSE dimana model terbaik yang dipilih adalah model dengan RMSE terkecil. Model ARIMA pada enam stasiun curah hujan menunjukkan akurasi yang lebih baik untuk 54 periode ke depan dibandingkan dengan model Ensemble ARIMA.
\end{abstract}

Kata Kunci: ARIMA, curah hujan dasaharian, ensemble

Apel merupakan salah satu komoditas utama di Jawa Timur dan ikon Kota Batu, Malang. Hujan adalah unsur iklim yang sangat mempengaruhi produksi buah apel, karena berpengaruh pada pertumbuhan dan perkembangan tanaman apel, baik secara langsung terhadap ketersediaan air dan tidak langsung melalui kelembaban udara dan tanah dan radiasi matahari. Suhardjo dalam Irawan (2007) menyebutkan bahwa curah hujan yang tinggi saat berbunga akan mengakibatkan bunga gugur sehingga tanaman apel tidak berbuah. Pada rentang tahun 2007 hingga 2010 terjadi penurunan jumlah produksi tanaman apel yaitu dari 1.425.116 kwintal turun menjadi 842.799 kwintal (Dinas Pertanian dan Kehutanan kota Batu). Kondisi ini disebabkan banyaknya petani yang beralih menanam komoditas lain seperti buah jeruk, sayur mayur, dan bunga. Selain itu, kondisi iklim di kota Batu tidak mendukung sehingga mengakibatkan produktivitas tanaman apel berkurang dan program penanaman kembali tanaman apel juga dinilai tidak efisien mengingat masa tanam buah apel adalah 5 tahun (Anonim, 2010). Dengan adanya kondisi tersebut maka perlu upaya prakiraan iklim, khususnya curah hujan sehingga dapat digunakan untuk menentukan kalender tanam budidaya apel.

Curah hujan merupakan endapan berupa cairan yang jatuh ke permukaan bumi dengan variabilitas yang besar dalam ruang dan waktu. Berdasarkan skala ruang, variabilitasnya sangat 
dipengaruhi oleh letak geografi, topografi, ketinggian tempat, arah angin umum, dan letak lintang. Keragaman curah hujan terjadi juga secara lokal di suatu tempat, yang disebabkan oleh adanya perbedaan kondisi topografi seperti adanya bukit, gunung atau pegunungan yang menyebabkan penyebaran hujan yang tidak merata (Irawan, 2007).

Metode peramalan curah hujan pada saat ini semakin berkembang. Saat ini telah dikenal metode kombinasi dari metode individu yang menggunakan konsep penggabungan beberapa model peramalan. Munculnya ide metode ini dikarenakan hasil kesimpulan dari M3-Competition yang menyebutkan bahwa penggabungan dari beberapa metode ramalan akan meningkatkan akurasi ramalan. Berdasarkan hasil M3 Competition tersebut, dalam studi ini akan digunakan metode ARIMA dan ensemble ARIMA untuk meramalkan curah hujan di Kota Batu. Keakuratan model dalam prediksi diukur berdasarkan kriteria RMSE dimana model terbaik yang dipilih adalah model dengan RMSE terkecil. Penelitian ini diharapkan dapat membantu pihak terkait dalam merencanakan, mengatur, menentukan dan mengevaluasi berbagai program pembangunan terkait program peningkatan produktivitas pertanian.

Model ARIMA meliputi model ARIMA non-musiman dan musiman. Telah disebutkan sebelumnya bahwa sederetan data asli $Y_{1}, Y_{2}, \ldots Y_{n}$ harus ditransformasikan terlebih dahulu menjadi nilai yang stasioner (Bowerman dan O'Connell, 1993). Jika data tidak stasioner terhadap mean, maka dilakukan differencing dengan formulasi:

$$
Y_{t}^{1}=Y_{t}-Y_{t-1}
$$

Secara umum, model ARIMA dapat dituliskan dengan ARIMA $(p, d, q)(P, D, Q)^{s}$ dengan persamaan seperti berikut:

$$
\phi_{p}(B) \Phi_{p}\left(B^{S}\right)(1-B)^{d}\left(1-B^{S}\right)^{D} Y_{z}=\theta_{0}+\theta_{q}(B) \theta_{\zeta}
$$

$$
\begin{aligned}
& \text { dengan: } \\
& p=\text { orde dari autoregressive } \\
& d=\text { orde dari differencing } \\
& q=\text { orde dari moving average } \\
& S=\text { periode musiman } \\
& P=\text { orde dari autoregressive musiman } \\
& D=\text { orde dari differencing musiman } \\
& Q=\text { orde dari moving average musiman } \\
& \phi_{p}(B) \quad=1-\phi_{1} B-\phi_{2} B^{2}-\cdots-\phi_{p} B^{p} \\
& \theta_{q}(B) \quad=1-\theta_{1} B-\theta_{2} B^{2}-\cdots-\theta_{q} B^{q} \\
& \Phi_{P}\left(B^{S}\right)=1-\Phi_{1} B^{S}-\Phi_{2} B^{2 S}-\cdots-\Phi_{p} B^{P S} \\
& \Theta_{Q}\left(B^{S}\right)=1-\Theta_{1} B^{S}-\Theta_{2} B^{2 S}-\cdots-\Theta_{Q} B^{Q S}
\end{aligned}
$$

Jika order dalam persamaan di atas adalah nol, maka persamaan tersebut merupakan model non-musiman. Sebaliknya, jika order S pada persamaan tersebut besarnya tidak nol, maka persamaan tersebut merupakan model musiman.

Pada kasus time series, outlier mempengaruhi model. Outlier dikelompokkan menjadi Additive Outlier (AO), Innovative Outlier (IO), Level Shift (LS), dan Transitory Change (TC). Additive 
Outlier hanya berpengaruh pada pengamatan ke-T. Innovative Outlier, Level Shift, dan Transitory Change memberi pengaruh pada pengamatan ke-T, $T+1, \ldots$ dan seterusnya. Model dengan outlier secara umum dapat ditulis sebagai berikut (Wei, 2006) :

$$
Y_{t}=\sum_{j=1}^{k} \omega_{j} v_{j}(B) I_{j}^{\left(T_{j}\right)}+\frac{\theta(B)}{\phi(B)} a_{t}
$$

Dengan:

$$
\begin{aligned}
& I_{j}^{\left(T_{j}\right)}=\text { variabel yang menunjukkan adanya outlier } \mathrm{p} \\
& I_{A}^{\left(T_{j}\right)}=\left\{\begin{array}{l}
1, t=T_{j} \\
0, t \neq T_{j}
\end{array}\right. \\
& I_{S}^{\left(T_{j}\right)}=\left\{\begin{array}{l}
1, t \geq T_{j} \\
0, t<T_{j}
\end{array}\right. \\
& v_{j}(B)=1 \text { untuk AO } \\
& v_{j}(B)=\frac{\theta(\mathrm{B})}{\phi(\mathrm{B})} \text { untuk IO } \\
& v_{j}(B)=\frac{1}{(1-B)} \text { untuk LS } \\
& v_{j}(B)=\frac{1}{(1-\delta B)} ; 0<\delta<1 \text { untuk TC }
\end{aligned}
$$

Berikut adalah penjelasan tentang model ensemble untuk meramalkan curah hujan di Kota Batu. Peramalan ensemble merupakan teknik peramalan yang mengombinasikan output dari beberapa metode peramalan sebagai nilai suatu ramalan. Dalam perkembangannya, selama 15 tahun terakhir ini dapat ditunjukkan bahwa peramalan ensemble telah menjadi salah satu teknik yang banyak digunakan dalam peramalan cuaca (Leutbecher dan Palmer, 2008).

Ada dua metode yang paling sering digunakan untuk mengombinasikan output yang berbeda dari anggota ensemble (Zaier et al., 2010), yaitu metode rata-rata (averaging) dan penggabungan (stacking). Ensemble averaging menggunakan metode rata-rata yaitu output dari ensemble diperoleh dengan menghitung rata-rata dari output model anggota ensemble. Misalkan $N$ adalah jumlah dari anggota-anggota model individual dalam suatu ensemble, suatu kombinasi fungsi $f$ yaitu:

$$
\hat{y}_{i}=f\left(\hat{\theta}_{i}^{k}\right), i=1,2, \ldots, m
$$

Dengan $\hat{y}_{i}$ adalah suatu nilai prediksi dari pengamatan $i$ yang diperoleh dari $k$ model dan bentuk dari fungsi $f$ adalah

$$
f\left(\hat{y}_{i}^{k}\right)=\frac{1}{N} \sum_{k=1}^{N} \hat{y}_{i}^{k}
$$

Stacking adalah suatu metode umum yang menggunakan suatu kombinasi dari suatu model level lebih tinggi dan model level lebih rendah untuk mencapai suatu akurasi prediksi yang lebih tinggi. Breiman dalam Zaier et al. (2010) menyarankan minimisasi suatu fungsi $G$ untuk memperbaiki kemampuan generalisasi dari suatu model, yaitu:

$$
G=\sum_{i=1}^{m}\left[y_{i}-\sum_{k=1}^{N} c_{k} \hat{y}_{i}^{k}\right], \quad c_{k}>0
$$


Koefisien-koefisien $\hat{c}_{1}, \hat{c}_{2}, \ldots, \hat{c}_{3}$ dalam persamaan 5 diestimasi untuk membentuk atau mengkonstruksi suatu nilai prediksi akhir dari suatu ensemble, yaitu:

$$
\hat{y}_{1}=\sum_{k=1}^{N} c_{k} \hat{y}_{1}^{k}, i=1,2, \ldots, m
$$

Autoregressive Integrated Moving Average merupakan metode peramalan yang dikenalkan oleh George E. P. Box dan Gwilym M. Jenkins pada tahun 1960-an dimana sampai saat ini teknik peramalan ini masih banyak digunakan. Salah satu penelitian terkait curah hujan yang menggunakan metode ini dilakukan oleh Chadsuthi et al (2012). Chadsuthi et al (2012), meneliti dampak curah hujan dan suhu di daerah Thailand bagian utara dan timur laut terhadap penyakit leptospirosis. Dalam penelitiannya, diperoleh bahwa faktor yang berpengaruh terhadap penyakit leptospirosis untuk daerah Thailand bagian utara adalah curah hujan dan model ARIMA terbaik yang didapatkan adalah ARIMA dengan delapan lag. Sedangkan untuk daerah Thailand bagian timur laut, faktor yang berpengaruh terhadap penyakit leptospirosis adalah curah hujan dan suhu, dimana model ARIMA terbaik untuk curah hujan adalah sepuluh lag sedangkan untuk suhu adalah delapan lag. Selama 15 tahun terakhir, metode individu ini dinilai kurang memuaskan untuk meramalkan data yang mengandung unsur ketidakpastian sehingga berkembang metode kombinasi seperti metode ensemble yang digunakan untuk peramalan cuaca khususnya curah hujan.

Metode-metode tersebut merupakan suatu bentuk perkembangan metode peramalan yang digunakan oleh ilmuwan di dunia untuk mendapatkan alternatif peramalan yang menghasilkan akurasi terbaik. Namun, semakin kompleks metode yang digunakan belum tentu metode tersebut menghasilkan akurasi yang lebih baik dibandingkan metode sederhana (klasik). Hal ini disebutkan dalam hasil M-3 Competition (Makridakis dan Hibon, 2000) yaitu:

a. metode statistika yang canggih atau kompleks belum tentu memberikan akurasi yang lebih baik dibandingkan metode yang sederhana,

b. ranking relatif dari performansi metode-metode peramalan bervariasi dan bergantung pada ukuran akurasi yang digunakan,

c. akurasi ketika beberapa metode peramalan dikombinasikan, misalnya metode individu yang dikombinasikan, akan menghasilkan akurasi lebih baik jika dibandingkan dengan metode lain, dan

d. akurasi dari metode bergantung pada panjang horizon ramalan.

\section{METODE}

Pada penelitian ini digunakan beberapa data curah hujan dasaharian dari 6 stasiun curah hujan Kota Batu, yaitu stasiun Tlekung, Tinjumoyo, Temas, Pendem, Ngujung, dan Ngaglik. Data terdiri dari dua bagian, yaitu data in-sample (Januari 1996-Desember 2010) dan data out-sample (Januari 2011-Juni 2012). Data in-sample adalah data yang digunakan untuk membentuk model, sedangkan data out-sample adalah data yang digunakan untuk mengukur akurasi ramalan periode selanjutnya. Banyaknya data in-sample adalah 540 dan data out-sample sebanyak 54.

Langkah-langkah analisis dalam penelitian ini adalah :

1) Mendeskripsikan data rata-rata curah hujan dasaharian tiap stasiun curah hujan di Kota Batu.

2) Memodelkan dan mendapatkan ramalan rata-rata curah hujan dasaharian tiap stasiun curah hujan di Kota Batu dengan ARIMA. Peramalan dengan ARIMA, dimulai dengan tahap identifikasi, estimasi parameter dengan Conditional Least Square, uji signifikansi parameter 
dengan statistik uji $t$, dan uji diagnostik (residual berdistribusi normal dan white noise) yang mana jika tidak memenuhi asumsi residual berdistribusi normal diperlukan adanya analisis terhadap outlier. Tahap terakhir dari prosedur Box-Jenkins adalah mendapatkan ramalan data out-sample dengan ARIMA dan menghitung RMSE data out-sample.

3) Memodelkan dan mendapatkan ramalan rata-rata curah hujan dasaharian tiap stasiun curah hujan di Kota Batu dengan model ensemble. Ensemble multi model merupakan ensemble dengan anggota terdiri dari model-model ARIMA di tiap stasiun. Syarat dilakukannya peramalan dengan model ensemble adalah jumlah anggota ensemble sedikitnya 2 model. Ramalan dari semua kemungkinan model-model ARIMA yang sesuai kemudian digabungkan dengan metode averaging dan stacking sehingga ramalan hasil penggabungan ini disebut ramalan ensemble. Langkah selanjutnya adalah menghitung RMSE ramalan.

$R M S E=\sqrt{\frac{\sum_{t=1}^{N}\left(Y_{t}-\hat{Y}_{t}\right)^{2}}{N}}$

4) Membandingkan hasil ramalan dari ARIMA dengan model ensemble dan memilih metode terbaik berdasarkan kriteria RMSE out-sample terkecil.

5) Melihat konsistensi dari akurasi ramalan

\section{HASIL DAN PEMBAHASAN}

Curah hujan antar tempat mempunyai sifat dan karakteristik yang berbeda satu sama lain. Hal ini bergantung pada letak topografi, geografi, dan ketinggian tempat. Kota Batu, salah satu daerah di Kabupaten Malang, Jawa Timur merupakan daerah pegunungan dan menjadi sentra budidaya apel sehingga curah hujan sangat penting pengaruhnya dalam produksi buah apel.

Tabel 1. Mean dan Standar Deviasi Stasiun Curah Hujan Kota Batu

\begin{tabular}{lcccc}
\hline Stasiun Curah Hujan & Mean & Standar Deviasi & Min & Max \\
\hline Tlekung & 4,21 & 5,28 & 0 & 23,64 \\
Tinjumoyo & 4,90 & 5,87 & 0 & 26,55 \\
Temas & 4,52 & 5,61 & 0 & 27,09 \\
Pendem & 4,74 & 5,66 & 0 & 33,63 \\
Ngujung & 4,69 & 5,48 & 0 & 22,80 \\
Ngaglik & 4,45 & 5,53 & 0 & 27,10 \\
\hline
\end{tabular}

Tabel 1 merupakan deskripsi dari rata-rata curah hujan dasaharian di enam stasiun curah hujan Kota Batu, Malang. Curah hujan antar tempat mempunyai sifat dan karakteristik yang berbeda satu sama lain. Berdasarkan analisis statistika deskriptif, rata-rata curah hujan tiap stasiun curah hujan di Kota Batu berkisar 4 mm-5 mm/dasahari dimana rata-rata tertinggi terjadi pada stasiun curah hujan Tinjumoyo, yang berarti pada stasiun ini sering terjadi hujan dengan intensitas tinggi, sedangkan rata-rata curah hujan dasaharian terendah terjadi pada stasiun curah hujan Tlekung. Stasiun Tinjumoyo juga memiliki tingkat keragaman curah hujan tertinggi yang terjadi pada rentang waktu Januari 1996 - Desember 2010, dengan standar deviasi 5,86 dan sebaliknya, tingkat keragaman terendah terjadi di stasiun curah hujan Tlekung sebesar 5,35. Stasiun curah hujan Pendem memiliki curah hujan rata-rata dasaharian terekstrim dimana keadaan ini terjadi pada dasaharian ke-III Februari 2009. Bulan basah di tahun 2008 terjadi pada bulan Nopember hingga 
Februari 2009 dan bergeser pada bulan Nopember 2009 hingga Mei 2010. Hal ini menunjukkan pada tahun 2010 terjadi musim hujan yang panjang.

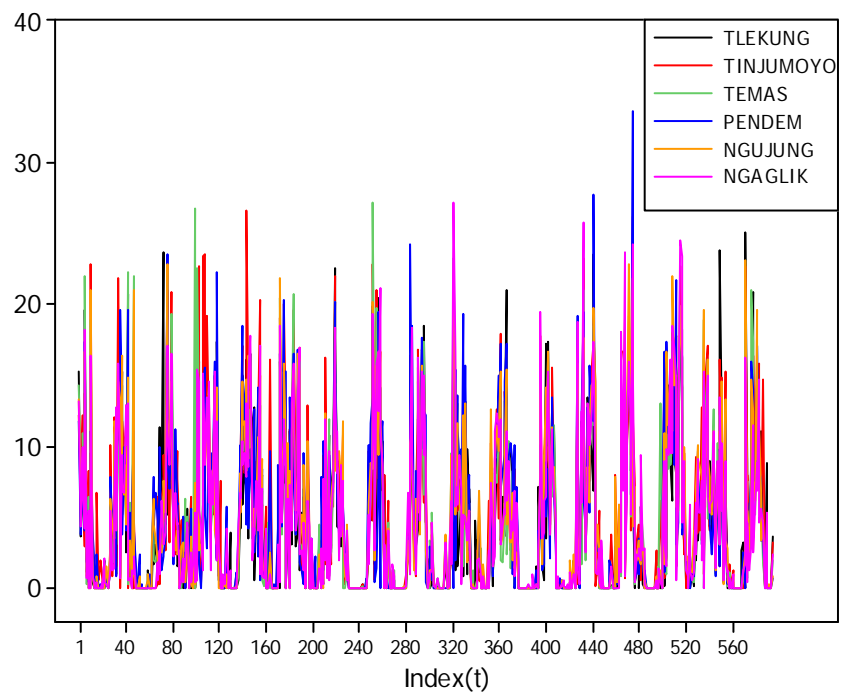

Gambar 1. Plot time series rata-rata curah hujan dasaharian

Gambar 1 menunjukkan plot time series rata-rata curah hujan dasaharian di enam stasiun curah hujan Kota Batu, dan Gambar 1 menunjukkan bahwa curah hujan di enam stasiun mempunyai pola yang sama. Terdapat curah hujan yang ekstrim di beberapa waktu pada selang bulan Januari 1996 sampai Juni 2012 pada semua stasiun.

Model ARIMA dilakukan dengan prosedur Box Jenkins, mulai dari identifikasi melalui ACFPACF data yang telah stasioner, estimasi parameter dengan Conditional Least Square, uji signifikansi parameter, dan uji diagnostik (residual berdistribusi normal dan white noise), dan peramalan. Pada tahap awal identifikasi model, asumsi yang harus dipenuhi adalah data harus stasioner dalam varian dan mean. Stasioneritas data dalam varian dapat dilihat dari plot Box-Cox, sedangkan stasioneritas data dalam mean dapat dilihat dari plot fungi korelasi (ACF). Jika data tidak stasioner terhadap mean, maka dilakukan differencing. Pada kasus ini, tidak dilakukan transformasi Box-Cox karena pada beberapa penelitian disebutkan bahwa pengaruh transformasi terhadap akurasi ramalan tidak signifikan. Untuk memeriksa kestasioneran dalam mean, dilakukan identifikasi terhadap plot ACF.

Pada stasiun curah hujan Tlekung, data tidak stasioner terhadap mean dan terdapat indikasi adanya pola turun lambat pada lag musiman 36. Dari plot ACF-PACF setelah dilakukan differencing 36 didapatkan dua model ARIMA yang sesuai, yaitu ARIMA $(0,0,0)(0,1,1)^{36}$ dan $\operatorname{ARIMA}((29), 0,(29))$ $(0,1,1)^{36}$. Sedangkan untuk stasiun curah hujan lain, model ARIMA yang sesuai terdapat pada Tabel 2.

Model-model tersebut mempunyai estimasi parameter yang signifikan dan white noise tetapi tidak berdistribusi normal. Hal ini dikarenakan terdapat banyaknya outlier pada data yang merupakan data ekstrim. Dengan mengasumsikan residual telah berdistribusi normal, maka model ARIMA terbaik berdasarkan kriteria RMSE out-sample terkecil untuk setiap stasiun ditampilkan pada Tabel 3. 
Tabel 2. Model ARIMA Rata-Rata Curah Hujan Dasaharian yang Sesuai Untuk Tiap Stasiun

\begin{tabular}{lc}
\hline Stasiun & Model \\
\hline \multirow{2}{*}{ Tlekung } & $\operatorname{ARIMA}(0,0,0)(0,1,1) 36$ \\
& $\operatorname{ARIMA}((29), 0,(29))(0,1,1) 36$ \\
\hline \multirow{2}{*}{ Tinjumoyo } & $\operatorname{ARIMA}(1,0,1)(0,1,1) 36$ \\
& $\operatorname{ARIMA}((5), 0,1)(0,1,1) 36$ \\
\hline \multirow{3}{*}{ Temas } & $\operatorname{ARIMA}(1,0,1)(0,1,1) 36$ \\
& $\operatorname{ARIMA}(0,0,0)(0,1,1) 36$ \\
& $\operatorname{ARIMA}(0,0,1)(0,1,1) 36$ \\
\hline \multirow{3}{*}{ Pendem } & $\operatorname{ARIMA}(0,0,0)(0,1,1) 36$ \\
& $\operatorname{ARIMA}(1,0,0)(0,1,1) 36$ \\
& $\operatorname{ARIMA}(0,0,1)(0,1,1) 36$ \\
\hline \multirow{3}{*}{ Ngujung } & $\operatorname{ARIMA}((2), 0,2)(0,1,1) 36$ \\
& $\operatorname{ARIMA}(1,0,1)(0,1,1) 36$ \\
\hline \multirow{2}{*}{ Ngaglik } & $\operatorname{ARIMA}(1,0,0)(0,1,1) 36$ \\
& $\operatorname{ARIMA}(1,0,0)(0,1,1) 36$ \\
\hline
\end{tabular}

Tabel 3. Model ARIMA Terbaik Rata-Rata Curah Hujan Dasaharian Tiap Stasiun

\begin{tabular}{lllll}
\hline Stasiun & Model ARIMA & $\begin{array}{l}\text { Jumlah } \\
\text { Outlier }\end{array}$ & $\begin{array}{l}\text { RMSE out- } \\
\text { sample }\end{array}$ & $\begin{array}{l}\text { Kenormalan } \\
\text { Residual }\end{array}$ \\
\hline Tlekung & ARIMA $(0,0,0)(0,1,1) 36$ & 55 & 5,177 & Tidak \\
Tinjumoyo & ARIMA $(1,0,1)(0,1,1) 36$ & 53 & 4,905 & Tidak \\
Temas & ARIMA $(0,0,0)(0,1,1) 36$ & 95 & 4,442 & Tidak \\
Pendem & ARIMA $(0,0,1)(0,1,1) 36$ & 42 & 4,067 & Tidak \\
Ngujung & ARIMA $(1,0,0)(0,1,1) 36$ & 99 & 4,593 & Tidak \\
Ngaglik & ARIMA $(0,0,1)(0,1,1) 36$ & 75 & 4,192 & Tidak \\
\hline
\end{tabular}

Salah satu cara mengatasi ketidaknormalan residual akibat outlier adalah memasukkan outlier tersebut ke dalam model ramalan. Pada data rata-rata curah hujan dasaharian di stasiun Tlekung terdapat 55 outlier yang mempengaruhi sebaran residual model. Pemodelan $\operatorname{ARIMA}(0,0,0)(0,1,1)^{36}$ dengan outlier tersebut kemudian diuji signifikansi parameter serta kenormalan dan white noise dari residual model, seperti yang tersaji pada Tabel 4. Hasil pengujian parameter menunjukkan bahwa semua parameter dan outlier telah signifikan pada taraf 0,05. Model ini telah memenuhi asumsi white noise namun tidak memenuhi asumsi residual berdistribusi normal. Sama halnya dengan stasiun Tlekung, model ARIMAX untuk stasiun lain juga tidak memenuhi asumsi residual berdistribusi normal. Dari analisis ini dapat disimpulkan bahwa pada Januari 1996 hingga Desember 2010 banyak terjadi curah hujan yang sangat tinggi (di atas rata-rata).

Selain dengan ARIMA, dilakukan pemodelan dengan metode kombinasi yaitu model ensemble dimana model ini merupakan model yang menggabungkan beberapa hasil ramalan yang sedikitnya terdiri dari 2 model. Adapun anggota dari ensemble ARIMA adalah model-model ARIMA dan ARIMAX di masing-masing stasiun curah hujan Kota Batu. Metode yang digunakan untuk menggabungkan hasil ramalan tersebut adalah metode averaging dan stacking. 
Tabel 4. Model ARIMAX Rata-Rata Curah Hujan Dasaharian Tiap Stasiun

\begin{tabular}{llcc}
\hline Stasiun & Model ARIMAX & Jumlah Outlier & $\begin{array}{c}\text { RMSE } \\
\text { Out-sample }\end{array}$ \\
\hline Tlekung & ARIMAX $(0,0,0)(0,1,1) 36$ & 140 & 5,474 \\
Tinjumoyo & ARIMAX $(0,0,1)(0,1,1) 36$ & 27 & 5,977 \\
Temas & ARIMAX $(0,0,(1,4,5,8,10,15))(0,1,1) 36$ & 2 & 5,872 \\
Pendem & ARIMAX $(0,0,(1,31))(0,1,1) 36$ & 126 & 4,613 \\
Ngujung & ARIMAX $(1,0,0)(0,1,1) 36$ & 59 & 5,678 \\
Ngaglik & ARIMAX $(0,0,1)(0,1,1) 36$ & 71 & 5,148 \\
\hline
\end{tabular}

Penggabungan dengan averaging adalah merata-ratakan hasil ramalan setiap periode sedangkan penggabungan dengan stacking adalah meregresikan nilai ramalan in-sample kemudian koefisien dari model regresi tersebut digunakan untuk menggabungkan ramalan anggota dari ensemble. Hasil dari peramalan dengan metode averaging dan stacking yang terdapat pada Tabel 5 untuk tiap stasiun menunjukkan bahwa metode penggabungan averaging mempunyai akurasi yang lebih baik dibandingkan metode penggabungan stacking pada lima dari enam stasiun curah hujan Kota Batu.

Tabel 5. Model Ensemble Terbaik Tiap Stasiun

\begin{tabular}{|c|c|c|c|c|}
\hline \multirow{2}{*}{ Stasiun } & \multicolumn{2}{|c|}{ RMSE in-sample } & \multicolumn{2}{|c|}{ RMSE out-sample } \\
\hline & Averaging & Stacking & Averaging & Stacking \\
\hline Tlekung & 3,331 & $2,476^{*}$ & $5,142^{*}$ & 5,315 \\
\hline Tinjumoyo & 4,011 & $2,713^{*}$ & $5,151^{*}$ & 5,972 \\
\hline Temas & 3,781 & $1,782^{*}$ & $4,696^{*}$ & 5,832 \\
\hline Pendem & 4,188 & $3,156^{*}$ & $4,138 *$ & 4,607 \\
\hline Ngujung & 3,551 & $1,719 *$ & $4,785^{\star}$ & 5,669 \\
\hline Ngaglik & 3,542 & $2,199 *$ & $4,395^{\star}$ & 5,137 \\
\hline
\end{tabular}

Tiap metode peramalan mempunyai tingkat akurasi yang berbeda. Perbandingan akurasi peramalan dilakukan untuk mengetahui metode yang paling sesuai untuk meramalkan rata-rata curah hujan dasaharian tiap stasiun di Kota Batu dan melihat konsistensi akurasi metode. Model yang akan dibandingkan adalah model terbaik berdasarkan kriteria RMSE terkecil dari masingmasing metode, yaitu model ARIMA dan model ensemble tiap stasiun. Peramalan dilakukan selama 54 periode ke depan yaitu mulai dasaharian I Januari 2011 sampai dasaharian III Juni 2012. Langkah-langkah yang dilakukan untuk mendapatkan konsistensi ramalan pada masing-masing metode dimulai dari menghitung nilai RMSE out-sample $k$-periode ramalan dari masing-masing model terbaik per metode yang dalam penelitian ini dihitung sampai 54 periode ramalan. Untuk semua stasiun, metode ensemble dengan averaging mempunyai akurasi lebih baik dalam peramalan rata-rata curah hujan dasaharian yang ditunjukkan nilai RMSE out-sample lebih kecil dibandingkan dengan stacking. Dari hasil analisis, dapat disimpulkan bahwa metode ARIMA mempunyai akurasi lebih baik dibandingkan model ARIMAX dan ensemble ARIMA (lihat Tabel 3, 4, dan 5). Hal ini menunjukkan bahwa ARIMA mempunyai hasil ramalan yang lebih baik dalam peramalan jangka panjang rata-rata curah hujan dasaharian di Kota Batu.

\section{SIMPULAN}

Untuk semua stasiun, model-model ARIMA dan model ensemble yang didapatkan berbedabeda. Namun, terdapat kemiripan pola curah hujan untuk keenam stasiun. Pada model ARIMA, 
asumsi kenormalan residual tidak terpenuhi. Namun model ini merupakan model terbaik untuk meramalkan 54 periode ke depan untuk stasiun Tlekung, Tinjumoyo, Temas, Pendem, Ngujung, dan Ngaglik. Hal ini membuktikan bahwa metode yang lebih kompleks terkadang tidak lebih baik dari metode yang peramalan yang sederhana (M-3 Competition). Namun, perlu adanya evaluasi keakuratan tiap model untuk peramalan jangka pendek seperti 1 sampai 6 tahap ke depan karena memungkinkan adanya perbedaan hasil akurasi.

\section{REFERENSI}

Anonim. (2010). Edukasi. Diambil pada tanggal 9 Oktober 2012 dari: http://www.dirgantara-lapan.or.id) Bowerman, B.L., and O'Connell, R.T. (1993). Forecasting and time series: an applied approach. $3^{\text {rd }}$ edition. California: Duxbury Press.

Chadsuthi, S., Modchang, C., Lenbury, Y., lamsirithaworn, S., \& Triampo, W. (2012). Modeling seasonal leptospirosis transmission and its association with rainfall and temperature in Thailand using time-series and ARIMAX analyses. Asian Pacific Journal of Tropical Medicine, 5 (7), hal.539-546.

Irawan, D. (2007). Potensi pengembangan tanaman apel (malus sylvestris mill) berdasarkan aspek agroklimat di Jawa Timur. Tugas Akhir Institut Pertanian Bogor Departemen Geofisika dan Meteorologi Fakultas Matematika dan Ilmu Pengetahuan Alam (Tidak dipublikasikan).

Leutbecher, M., \& Palmer, T. N. (2008). Ensemble forecasting. Journal of Computational Physics , hal. 3515-3539.

Makridakis, S., \& Hibon, M. (2000). The M-3 Competition: results, conclusions and implications. International Journal of Forecasting. 16. hal. 451-476.

Wei, W.W.S. (2006). Time series analysis, univariate and multivariate methods. Canada: Addison Wesley Publishing Company.

Zaier, I., Shu, C., Ouarda, T., Seidou, O., \& Chebana, F. (2010). Estimation of ice thickness on lakes using artificial neural network ensembles. 